\section{Archæology and Tradition}

How far it is justifiable or even permissible to make use of tradition or 'folk-memory' in the interpretation of archæological data and the results of archæological excavation has been the subject of much argument. Some, like Lord Raglan, regard it as almost or completely valueless, while others would concede that in the reconstruction of prehistory, legend and folk-lore may sometimes afford a valuable clue to cultural or racial impact and subsequent changes in style, technique and practice. The question is one of no little importance in the preand early history of the British islands, where the traditions and lore of the Celtic-speaking peoples should be a mine of information as yet far from fully explored from this aspect. It is not often, however, that it is possible to bring a tradition to the bar of judgment and decide upon its value so conclusively as have Dr. F. J. North and Mr. W. F. Grimes in "The Legend of Llys Helig-its Origin and Significance" (Supplement to the Proceedings, Llandudno, Colwyn Bay and District Field Club, Llandudno, 1940. Pp. $\mathrm{x}+67$, with 8 pls. Price 5s.).

Helig, the story goes, was a king of North Wales who flourished towards the end of the sixth century of our era, though the statements as to his lineage, etc., allow a margin of variation of some centuries in dating. At this period, it is said, an inundation overwhelmed his lands and a considerable portion was irretrievably lost. Llys Helig is the name given to a patch of seaweed-covered stones to be seen when the tide is at its lowest out to sea off Penmaenmawr. It is popularly regarded as the site of Helig's palace; and in 1864 an account of an expedition to view the 'sunken ruins' by Mr. Charlton Hall described them as "a grand old hall of magnificent dimensions". The authors of the present account have made an exhaustive analysis of the literary, historical, geographical, geological and archæological evidence, which points to the conclusion that much of what has been adduced as evidence is inadmissible; and that such valid evidence as there is demonstrates conclusively that the spot where the stones occur could not have been occupied by human beings at any period to which the legend is supposed to relate; while the final verdict of geologist and archæologist is that Llys Helig itself is a heterogeneous and unsorted assemblage of boulders representing the debris of a denuded hillock of boulder clay, and never has been the component part of any building or structure, even such as a weir.

\section{Seals in the Ancient East}

SEALs and sealings are so frequently the subject of reference and their importance so often stressed in accounts of archæological investigations in the ancient East which are directed to the interest of a public comprising others than the expert, that any attempt to extend a knowledge of the historical and cultural importance of the subject as well as of the intrinsic merits of the seals themselves is deserving of every encouragement. Dr. Henri Frankfort's excellent work, though by no means heavy reading, is probably too detailed for all but those who have made some headway in the subject. For those whose interest whether in the historical value or the æsthetic merits of the ancient seal has still to be aroused, a recent leaflet of the Field Museum of Natural History, Chicago ("Ancient Seals of the Near East" by Richard A. Martin. Leaflet 34, 1940. Pp. 4, with 24 illustrations and explanatory text. 25 cents) is an excellent provocative.

Twenty-two sealings are illustrated from reproductions in the frieze of the Babylonian Hall of the Museum. They cover some of the finest examples in the major periods in Near Eastern glyptic art from the fourth millennium B.c. (Jemdet Nasr) to the thirdfourth century A.D. (Sassanid), when the pictorial stamp seal of the Near East was drawing near its end. Among the more notable examples included are seals of the Agade period when the art reached its highest expression, the Ur-Nammu seal of the twenty-third century B.c. with its remarkably fine type of Babylonian writing, the highly ornamental Hittite seal of the fourteenth century B.c. in which four Gilgamesh figures in a wheel recall the early origin of the swastika, and last but not least for its historical significance the Harappa seal, showing elephant, rhinoceros and crocodile, found in Mesopotamia but unquestionably imported from the Indus Valley. The explanatory text which accompanies each illustration gives such historical and mythological detail as is adequate for understanding of the subject-matter of each seal impression. Technically the illustrations are almost beyond criticism.

\section{Mound Builders' Temple, Ohio.}

Explonation of a mound near North Benton, Ohio, has brought to light the remains of a structure identified as a temple in which a number of objects are apparently new to knowledge of the culture of the Mound Builders. The mound was excavated by Mr. Roy Saltman and $\mathrm{Mr}$. Willis H. Magrath. It has been assigned by Mr. Richard I. Morgan, curator of archæology in the Ohio State University, to the Hopewellian phase, the most advanced of the Mound Builder culture, which extended from Ohio down the Mississippi and Tennessee valleys. In an account of the excavation (Scientific American, August 1940), it is stated that within a circle of stone slabs there was evidence of an inner wall of wood in the form of charred stumps, which had supported a circular building nearly $70 \mathrm{ft}$. in diameter. A corridor from a gateway in the west side led to a fireplace in the middle of the temple floor. Stone altars and clay cones flanking the corridor bore charred bones and offerings of stone implements, mica, galena and copper.

The most striking feature of the temple was the figure of an eagle of white sandstone flags on an understructure of moulded clay, which measured $32 \mathrm{ft}$. across and $16 \mathrm{ft}$. from head to tail. It was headed towards the rising sun. Overlying the wings were two human skeletons, male and female. Numerous broken fragments of human skull bones and similar fragments on the nearby altar stone suggest 
human sacrifice as part of a burial ceremonial. Not only is the eagle figure unique, but also human sacrifice is a new element in finds in other branches of the Hopewellian culture. The culture of the Mound Builders, which developed between the beginning of the Christian era and Columbian times, had disappeared before the arrival of Europeans. The suggested connexion between this culture and that of Mexico and Central America might well account for the appearance of human sacrifice, to which the inhabitants of Mexico were particularly addicted.

\section{Murder by Children and Adolescents}

IN his inaugural thesis (Thèse de Paris, No. 108; 1940), Dr. Louis Begon, who records seven cases of attempted murder committed by males aged fourteen to nineteen, states that the motives for murder at this age show a much greater variety and are much more complicated than in the case of adults. The medicopsychological examination of cases of murder by young persons is of considerable practical interest both as regards the outlook of the case and the prognosis. The offenders may be classified in three different groups. The first consists of those guilty of a single offence. In such cases the prognosis is good, and a relapse is not likely to occur, provided that a change is made in the environment, which has an important influence on the determination of the act. The second group consists of those in whom murder is the result of disease. In such cases internment is required. The third group is formed by abnormal persons who are not really insane or suitable for detention in an asylum, but are dangerous individuals against whom society should be protected, in the absence of which protection a recurrence will probably happen.

\section{Tuberculosis in Mental Hospitals}

IN a paper (Amer. J. Psychiat., 96, 1335; 1940) based on his experience of pulmonary tuberculosis in mental hospitals during the last nine years, Dr. C. A. Wicks states that though the tuberculosis mortality rate for patients in the Ontario mental hospitals has shown a tendency to decrease since 1934, in 1936 the rate was fourteen times greater than that for the province as a whole. Approximately $2 \cdot 5$ per cent of 2,908 patients admitted to the Ontario mental hospitals during 1938 required isolation on account of X-ray findings in the chest. From the tuberculosis situation as it existed in January 1939 it was estimated that a central tuberculosis mental hospital would be required to accommodate approximately 5.2 per cent of the patients in Ontario mental hospitals. X-ray examination of the chest in 2,542 staff in the Ontario mental hospitals in 1937-38 showed that 0.6 per cent required treatment for tuberculosis. Since 1933, about 0.5 per cent of the employees have needed such treatment every year. About 1.7 per cent of 839 apparently healthy applicants or new staff in the Ontario mental hospital service during the calendar year 1938 showed X-ray evidence of pulmonary tuberculosis which was active or possibly active, thereby rendering them unacceptable for employment.

\section{Public Health and Advertising}

IN a paper read before the Health Officers' Section of the American Public Health Association (Amer. $J$. Public Health, 30, 880; 1940) Dr. K. E. Miller, medical director, U.S. Public Health Service, remarks that unrestrained advertising becomes a matter of public health concern primarily in connexion with those products which either directly or indirectly affect public health, such as foods, drugs and cosmetics. He points out that one of the most potent means for regulating unfair practices and protecting public health interests consists in the control of false and misleading advertisements, especially of those products which may be injurious to health. Apart from changes in the existing laws, State and local health forces can make valuable contributions to the success of the campaign against dangerous nostrums and the advertising of other medicinal products.

\section{Fatal Accidents in the United States}

According to the Journal of the American Medical Association of August 10, p. 470, the United States Bureau of the Census recently published a statistical study of fatal accidents in the six years 1933-1938. In 1933, fatalities from accidents totalled 90,932 , and thereafter the number rose to a maximum of 110,052 in 1936. Then it decreased to 93,805 in 1938 . Deaths caused by fires, which ranked seventh among all accidental causes during 1933-37, advanced to the sixth place in 1938. Figures for the successive years were 1,521 in $1933,1,752$ in $1934,1,581$ in 1935, 1,913 in $1936,1,688$ in 1937 and 1,650 in 1938. There were more victims from fire in the age group 5-9 than in any other group in 1938; there were 129 deaths in this group, which was $7 \cdot 8$ per cent of all persons burnt to death. The next largest number was in the group 50-54 with 109 deaths. Only $18 \cdot 3$ per cent of deaths from injury by fall occurred among persons less than forty-five years of age, who form 77 per cent of the population, but 55.8 per cent of the motor fatalities and $91 \cdot 3$ per cent of aeroplane fatalities were in this younger group.

\section{Improvement of Grassland}

GRassland improvement is the main theme of the July number of the Scottish Journal of Agriculture (23, No. 1, H.M. Stationery Office. Is., postage extra). Viewing the subject as a whole, a moderately longterm policy for higher farming is advocated, since facilities for improvement are now specially favourable, and stock-carrying capacity must be increased and fertility built up for the future. As a means of maintaining hill grazing as an economic proposition, the introduction of cattle, or a considerable increase in their numbers, is suggested. Bracken control is also dealt with in some detail, and the various machines recently used for this purpose described. With regard to the renovation of old pasture, practical 